\title{
CULTO A LOS ANIMALES
}

El principio que orienta la actitud del hombre andino frente a la Naturaleza, específicamente frente a la Tierra, rige su actitud frente al animal: la vida está por todas partes, $y$ junto con la vida, la conciencia. Si se perfila una familiaridad existencial entre el Hombre y la Naturale\%a, con mayor razón la encontraremos entre el hombre y el animal. Por lo tanto, se celebran fiestas en honor de los animales y se los venera. Volvemos a trascribir las palabras de Mirceo Elíade:

"Todo cuanto esté sobre la tierra constituye un conjunto ... hilos invisible unen la vegetación, el reino animal y el hombre, gracias a la vida que es la misma por todas partes". (1)

\section{LOS ANIMALES DOMESTICOS SON MIEMBROS DE LA FAMILIA}

El administrador de una hacienda comentaba:

- "Si se le pega a un hombre, puede ser que se deje pegar, pero si se toca a uno de sus animales, se rebelará con toda seguridad".

Se cuentan casos de campesinos atropellados por los carros, porque se aventaron bajo las ruedas de algún vehículo, con tal de salvar sus animales.

Los ejemplos podrían multiplicarse. Bastan los señalados para advertir que los aninales domésticos gozan del cariño de sus dueños: son miembras de la familia andina.

La civilización occidental relega a los animales a la condición de propiedad-objeto, con derecho de usar y de abusar de ellos, sin mayor reparo. Ciertamente este no es el planteamiento del mundo andino ni lo fue para los romanos, quienes definian al patrimonium en términos de familia pecuniaque.

El hombre andino quiere entrañablemente a sus animales.

La camaradería entre el hombre y el animal se enriquece con otros elementos:

- los animales provocan en el hombre un choque emocional de desconcierto: los unos por su tamaño, los otros por su fuerza o por su agilidad o por su fiereza o por su facultad de volar o la de vivir en el agua. 
Del desconcierto al asombro, del asombro al respeto, del respeto i la veneración, el camino es fácil de recorrer.

$\mathrm{Y}$ se llega a rendir culto a los animilns.

- Los venerados apus (espiritus de los cerros) son considerados como propietarios de los animales salvajes, motivo más para homenajear a éstos ;

-numerosas religiones atribuyen a los animales una función vicaria: es decir que son victimados en lugar de los humanos. Esta función religiosa vicaria queda claramente estampada en el episodio del sacrificio de Isaac en el Génesis, cap. XXII. La muerte de Jesucristo dió su solución plena a la voluntad sacrificial del hombre y puso punto final a la función vicaria de los animales. "Es imposible que la sangre de toros y machos cabrios borre pecados. Por eso, Ćristo, al entrar en el mundo, dijo a Dios: "No quieres sacrificio ni ofrenda de animales, sino que me has preparado un cuerpo... Entonces dije: aquí vengo para hacer tu voluntad, Oh Dios..." Heb. $\mathrm{X}, 4$ y sig. Para nosotros queda claro que, después de Jesucristo, los animales han cesado de ser víctimas oferendas. Para el pueblo andino, la evidencia no es tal.

\section{LA REVISTA}

NOTAS

(1) Mircea Eliade. op. cit. 